\title{
ASSESSMENT OF INUNDATION AREA AND WATER LEVEL OF THE TONLE SAP LAKE USING MULTI-SOURCE REMOTE SENSING DATA BETWEEN 2008 AND 2018
}

\author{
YAN, Y. ${ }^{1 \#}-$ HUANG, Y. Y. $.^{2 \#}-$ ZHAO, Y. J. ${ }^{1 *}-$ TONG, K. ${ }^{1}-$ LIANG, Y. L. ${ }^{3}$ \\ ${ }^{1}$ Key Laboratory of Environment Change and Resources Use in Beibu Gulf, Nanning Normal \\ University, Ministry of Education, Nanning 530001, China \\ (phone: +86-132-9781-2623) \\ ${ }^{2}$ Natural Resources Information Center of Nanning, Nanning 530021, China \\ (phone: +86-189-7882-9392) \\ ${ }^{3}$ School of Geography and Planning, Nanning Normal University, Nanning 530001, China \\ (phone: +86-187-7675-6017) \\ *Corresponding author \\ e-mail: yinjunzhao@nnnu.edu.cn; phone: +86-152-7713-3597 \\ ${ }^{\#}$ These authors contributed equally to this work \\ (Received $11^{\text {th }}$ Jun 2021; accepted $4^{\text {th }}$ Sep 2021)
}

\begin{abstract}
As the largest freshwater lake located in the most controversial transboundary river in Asia, the Tonle Sap Lake is one of the most productive ecosystems in the world. However, uncertainty remains because of the inability to measure nonlinear inundation dynamics in remote lakes at fine spatial and temporal resolutions, let along the water levels. This research attempted to explore the reliability of radar altimetry data to detect the inland water level of inundation areas, like that of Tonle Sap Lake over the past decade. The results indicated that the Jason-2 and Jason-3 radar altimetry data were able to retrieve water level with high accuracy $\left(\mathrm{R}^{2}=0.9232\right.$ and confidence coefficient of $\left.98 \%\right)$, and the composite index was proven to be the optimal method to identify inundation area of the Tonle Sap Lake compared to the single-band threshold method and modified normalized difference water index by applying Moderate Resolution Imaging Spectroradiometer Surface Reflectance products MOD09A1. The fluctuation trend of inundation area and water level were basically consistent with the precipitation, presenting a distinct lagging relationship. More important was the truth that the downstream water level had poor correlation with the upstream runoff both in flood period and non-flood periods $\left(\mathrm{R}^{2}=0.0542\right.$ and $\left.0.2873, p<0.01\right)$, which indicated that the upstream explorations over Lancang-Mekong River had little effects on the downstream water volume.
\end{abstract}

Keywords: composite index, Jason-2 and Jason-3 radar altimetry, lagging relationship, variation tendency, flood pulse

\section{Introduction}

As the most significant transnational river flowing through China, Laos, Burma, Thailand, Cambodia and Vietnam, the Lancang-Mekong River is also one of the most controversial transboundary rivers in the world. It contains the world's largest inland fishery and nourishes about a quarter of a billion people that lived in the river basin (Hecht et al., 2019). The river runs for approximately $4800 \mathrm{~km}$ and as it originates from the Qinghai-Tibet Plateau, so the elevation drop reaches up to $5000 \mathrm{~m}$ which makes it an abundant hydropower resource (Zhang et al., 2020). As a consequence, the exploitation of the river has led to international conflicts because different stakeholders competed for the allocation and utilization over the shared water resource ( $\mathrm{Li}$ et al., 
2019a). Especially the conflicts happened among upstream and downstream countries, which have attracted the attention of international community for a long time.

The Tonle Sap Lake, which is the largest freshwater lake and boundary lake of Lancang-Mekong River basin, is considered as the "heart of the Lower Mekong" due to the exceptional biodiversity and is also one of the most productive ecosystems in the world. It is a globally unique lake-floodplain system for its seasonal bi-directional hydrological characteristics, with the water inflows from Mekong River in rainy season and outflows during the dry season recurrently (Arias et al., 2014). So the water levels of Tonle Sap Lake vary from an average depth of less than $2 \mathrm{~m}$ in the dry season to over $10 \mathrm{~m}$ in the flood season being linked to the annual flood pulse governed by the flow of the Mekong River (Oeurng et al., 2019). Accordingly, the inundation area also varies significantly in both short-term (weeks to months) and long-term (years) scales (Kummu et al., 2014). Adding to this complexity is the rapid population growth, agricultural expansion and hydropower construction in the Mekong River basin (Arias et al., 2012; Larnberts and Koponen, 2008). Therefore, monitoring the current status of flood inundation and water levels in time and space accurately is important for local water resource management, ecological conservation and hydrological processes.

Whilst the regional significance of Tonle Sap Lake is undisputed, uncertainty remains because of an inability to measure or model nonlinear inundation dynamics in remote basins (for the vast and inaccessible nature of the Tonle Sap Lake) at fine spatial and temporal resolutions, let alone the water levels. The greatest challenge in addressing the problem is the lack of long-term in situ observation data, especially in transboundary basins where the data are not always shared publicly (Gleason and Hamdan, 2017). Remote sensing observations offer a unique opportunity to continuously monitor the large floodplain, although they could not replace in situ observations (Jahanbakhsh et al., 2017; Tangdamrongsub et al., 2016).

Abundant satellite images generated by various sensor types including visible/infrared (Amani et al., 2017; Schneider and Hook, 2010), SAR (Synthetic Aperture Radar) (Ding and Li, 2011; Millard and Richardson, 2013) are available for investigating inland water bodies. The free Landsat images which have a relatively high spatial resolution were extensively applied (Pekel et al., 2016). However, they are limited by the rather long 16 days repeat cycle and the frequent occurrence of cloud coverage. As microwave remote sensing data, SAR are able to detect the ground objects without been affected by clouds (Schlaffer et al., 2015). But as most SAR images are generated by commercial satellites, the researches were hindered by the data availability. And some free SAR data like Sentinel-1 are just available since 2014, which only cover a short span of time. In contrast, MODIS (Moderate Resolution Imaging Spectroradiometer) dataset with high-frequency measurements and medium resolution was particularly suitable to address both short- and long-term changes in inundation areas of moderate and large lakes (Feng et al., 2012). Previous studies have determined spatio-temporal flooding extent by applying a threshold approach to land surface reflectance, or spectral indexes from the MODIS image (Chen et al., 2013). A number of spectral indices have been explored including the Normalized Difference Vegetation Index (NDVI), Enhanced Vegetation Index (EVI), Land Surface Water Index (LSWI) and Normalized Difference Water Index (NDWI) and so on (Fan et al., 2020; Fayne et al., 2017). The results indicated that various derived indices presented different accuracy in regard to their ability to identify the inundation area (Kwak, 2017). In consequence, it is essential that the diverse indices must be evaluated on a case-by- 
case basis to determine the optimal method for further application, especially for the Tonle Sap Lake with periodic flooding.

Moreover, to better understand the hydrology of large river systems, information about the dynamics of inundation pattern alone is not sufficient, the water levels are also required. The satellite altimetry, which could provide long-term and repeated measurements nearly globally and operate under different weather conditions, was proved to be an effective technique to monitor inland water bodies although it was routinely monitor sea level changes over the global open ocean (Dubey et al., 2015). A number of past, present and planned satellite altimetry missions, such as European Remote Sensing (ERS-1/2) (1991-2000, 1995-2002), ENVIronmental SATellite (ENVISAT) (2002-2010), TOPEX/Poseidon(T/P) (1992-), JASON-1/2/3 (2001- , 20082016, 2016-present respectively) and CryoSat-2 (2010-present), are capable of monitoring inland water levels with different accuracy and space-time resolutions (Boergens et al., 2019; Breda et al., 2019; Maillard et al., 2015). However, the time span of these satellites varies considerably due to their launch time and working life, on account of which the application of long-term monitoring was confined.

Thanks to the uninterrupted succession of TOPEX/Poseidon, the Jason-1, Jason-2 and Jason-3 missions are on the same orbit (Kuo et al., 2015; Maiwald et al., 2016). The main advantages of using these continuous data records are not only the three missions on the same orbit comes from the "calibration phases", but also with same 10 days of orbit recurrence period which provide the highest temporal resolution (Huang et al., 2018). The consistently operating and short-repeat times make it possible to monitor both long-term and short-term water levels as they have been validated to have good data quality with accuracy on the order of decimeter (Wang et al., 2019). Although pioneering studies have attempted to document the changes of inland water levels (Biancamaria et al., 2018; Li et al., 2019b), the universality of the data for medium lakes and the usefulness of continuous altimetry techniques to retrieve water levels in Tonle Sap Lake are still need to be further explored. This study attempted to provide a comprehensive assessment of the variations of the inundation area as well as to explore water levels in the Tonle Sap Lake over the past decade, using various data sets delivered by remote sensing satellites.

\section{Materials and methods}

\section{Study area}

The Tonle Sap Lake is the largest freshwater lake in the Lancang-Mekong River basin and it is also the largest lake in Southeast Asia. The entire basin area is $85800 \mathrm{~km}^{2}$, accounting for $11 \%$ of the total drainage area (Fig. 1). It provides favorable irrigation conditions for the thousands of farmlands in the ambient plain areas, and its fishery supports the livelihood and nutrition of millions of people in Cambodia (Hecht et al., 2019). The aquatic biodiversity of the Tonle Sap Lake has been listed as a World Biosphere Reserve by UNESCO (United Nations Educational, Scientific and Culture Organization).

Driven by the Asian monsoon, the Tonle Sap Lake presents distinct seasonal changes in precipitation varied from 1000 to $1500 \mathrm{~mm}$ between the dry and rainy season. It plays an important role as a natural regulator in the hydrological environment of Mekong Delta, because excessive water inflows to the lake during the rainy season (May to 
October) and discharge to the lower area during the dry season (November to April) with up to $8000 \mathrm{~m}^{3} / \mathrm{s}$ out from the lake (Arias et al., 2014).

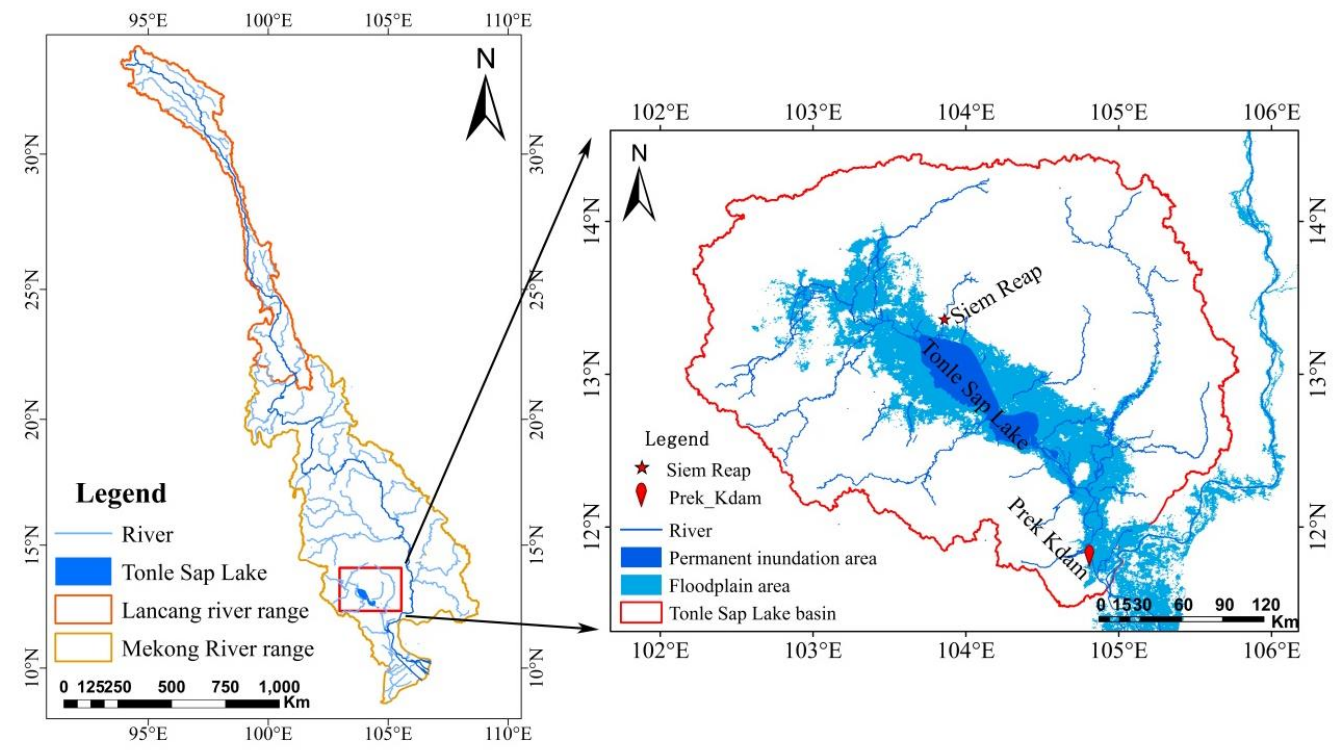

Figure 1. Location of the Tonle Sap Lake

This unique phenomenon causes the lake expands from $2500 \mathrm{~km}^{2}$ to over $16000 \mathrm{~km}^{2}$ and the water levels varies from less than $2 \mathrm{~m}$ in the dry season to more than $10 \mathrm{~m}$ in the rainy season. About $53.50 \%$ of the annual flow comes from the Mekong River and $12.50 \%$ from the precipitation (Kummu et al., 2014).

\section{Data source}

\section{MODIS products}

Launched as part of National Aeronautics and Space Administration (NASA)'s Earth Observation Sensor mission, MODIS is a multispectral instrument carried on two polarorbiting satellites, Terra and Aqua. The MODIS surface reflectance product MOD09A1 with Bands 1-7 and spatial resolution of $500 \mathrm{~m}$ from 2008-2018 were selected (https://modis.gsfc.nasa.gov/) to extract the inundation area of Tonle Sap Lake. This product is obtained by combining the best surface reflectance data of every pixel acquired during an eight-day period and selecting pixels of the highest quality based on a combination of low view angle, the absence of clouds or cloud shadow, and aerosol loading. There are two scene images, h27v07 and h28v07, covering the study area with sinusoidal projection. The original images were processed to ensure a whole image per month that fitting the study area.

\section{Radar altimetry data}

As T/P-family altimeters provided continuous measurements with a time interval of 10 days and resolution of $20 \mathrm{~Hz}$, Jason-2 (July 2008 - September 2016) and Jason-3 (February 2016 - August 2018) were selected in the study. To generate time series dataset of lake water levels, the geophysical data records (GDRs) from the Archiving, 
Validation and Interpretation of Satellite Oceanographic (AVISO) (https://www.aviso.altimetry.fr/) were acquired, which contained orbit heights, raw range measurements and geophysical corrections. As shown in Figure 2, there is one ground track of Jason family satellites passing over the Tonle Sap Lake.

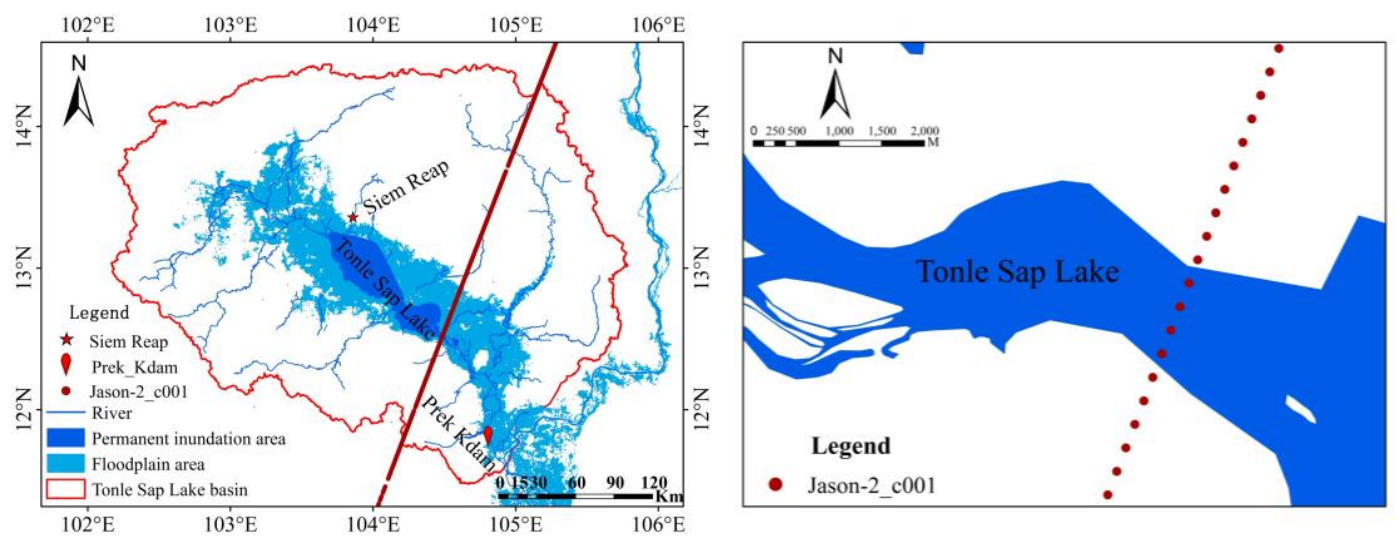

Figure 2. The orbit of Jason-2 at the exit of the Tonle Sap Lake

\section{Daily precipitation data of TRMM $3 B 42$}

The Tropical Rainfall Measuring Mission (TRMM) is jointly mission of NASA and the Japan Aerospace Exploration Agency. The 3B42V7 is product of TRMM Multisatellite Precipitation Analysis (TMPA) that takes input from several passive microwave sensors and has already been ground validated with the rain gauge data. The TRMM 3B42V7 Level 3 Product was provided by the Goddard Data Distribution Center of NASA (https://mirador.gsfc.nasa.gov/) with spatial resolution of $0.25^{\circ} \times 0.25^{\circ}$ in gridded format. The daily precipitation data from 2008 to 2018 was composited in Arcgis10.6 software to obtain monthly precipitation data and annual precipitation data.

\section{Meteorological data}

The Mekong River Commission's official website (MRC) is the only intergovernmental organization that works directly with the governments of Cambodia, the Lao People's Democratic Republic, Thailand and Vietnam to manage the water resources and sustainable development of the Mekong River. The water level data of the Prek Kdam hydrological station from 2008 to 2018 (http://ffw.mrcmekong.org/reportflood.php) was obtained from the MRC, which was published by the Cambodian Meteorological Bureau, also including wind speed, wind direction, solar radiation, sunshine time, relative humidity, evaporation, temperature, pressure, flow and precipitation. The precipitation data from 2009 to 2018 of Siem Reap where the city Tonle Sap Lake located was obtained from the Word Weather website (https://www.worldweatheronline.com).

\section{Methods}

\section{Inundation area extraction}

As Tonle Sap Lake is featured with seasonal variation, three types of approaches were applied to extract the inundation area and the optimal method was determined. 


\section{Single-band threshold method based on water body boundary}

The spectral response in the short-wave infrared is mainly dominated by water absorption bands, which was proved to be directly sensitive to soil and vegetation moisture content (Frappart et al., 2018). The reflectance in the short-wave infrared is assumed to be zero for water surface, so it is well suited to distinguish water from other ground objects. As short-wave infrared band of MOD09A1 surface reflectance data is the sixth band, so this approach is defined as Equation 1.

$$
\text { Prandb }<1
$$

where $\rho_{\text {band }}$ refers to the surface reflectance value in the short-wave infrared band of MOD09A1 (1628-1652 nm, band 6), $t$ is the threshold that segment the water and other ground objects. When the reflectance value below $t$, it will be defined as water body.

\section{Composite index}

Besides the above mentioned short-wave infrared band, the near infrared band is also sensitive to the surface object, especially the water and soil/vegetation. The reflectance in near infrared is low over water surface and high over vegetation, which is valuable to generate the efficient indices. This approach is based on the enhanced vegetation index (EVI), the land surface water index (LSWI) and the difference value between EVI (Eq. 2) and LSWI (DVEL) (Eqs.3-4), which was proved to be effective in quantifying the surface water extent (Normandin et al., 2018). The equations are as follows:

$$
\begin{aligned}
& \left.\mathrm{EVI}=2.5 \times\left(\text { Band }_{\mathrm{NIR}}-\text { Band }_{R e d}\right)\right)\left(\text { Band }_{\mathrm{NIR}}+\text { Band }_{R e d} \times 6-\text { Band }_{\text {IIe }} \times 7.5+1\right)
\end{aligned}
$$

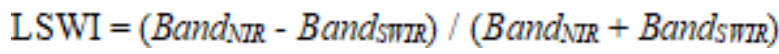

$$
\begin{aligned}
& \text { DVEL }=\text { EVI }- \text { LSWI }
\end{aligned}
$$

where for MODIS, Band Red $_{\text {, }}$ Band $_{\text {NIR }}$, Band $_{\text {Blue }}$ and $B a n d_{S W I R}$ refer to surface reflectance value of band 1 (621-670 nm), band $2(841-875 \mathrm{~nm})$, band $3(459-479 \mathrm{~nm})$ and band 6 $(1628-1652 \mathrm{~nm})$ respectively. The water body was extracted when the threshold range was EVI $<0.3$ and DVEL $<0.05$.

\section{Modified normalized difference water index}

The modified normalized difference water index (MNDWI) was developed by replacing the near infrared band used in normalized difference water index (NDWI) with the shortwave infrared band, since the water body was proved to have stronger absorbability in the shortwave infrared band than in the near infrared band. And a number of peer research works have turned out that MNDWI could extract water body with greater accuracy than NDWI (Du et al., 2016; Li et al., 2013). The MNDWI was defined as Equation 5:

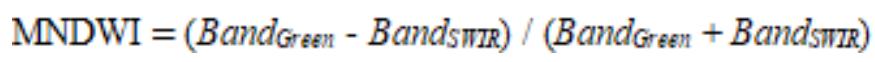

where Band $_{\text {Green }}$ refer to the surface reflectance value in the green band $(545-565 \mathrm{~nm}$, band 4) and Band ${ }_{S W I R}$ is the reflectance in the short-wave infrared band $(1628-1652 \mathrm{~nm}$, 
band 6). The optimal threshold to segment water body is 0 . When the reflectance greater than 0 , the pixel was defined as water body.

\section{Water level extraction}

The altimeter measures water level by transmitting radar pulse to lake's surface and measuring the vertical distance between the satellite and the lake surface. The lake level is the difference between the satellite's ellipsoidal height and the range (Eq. 6$)$.

$$
H=H_{\text {art }}-H_{\text {ram }}-H_{\text {hei }}-\Delta H_{\text {cor }}-0.71
$$

where $H$ is the corrected orthometric height; $H_{\text {alt }}$ represents the satellite altitude with respect to reference ellipsoid, $H_{\text {ran }}$ is the satellite measure range, $H_{h e i}$ refers to the height of geodetic datum to the reference ellipsoid, $\Delta H_{\text {cor }}$ represents the correction parameter and 0.71 is the vertical offset of the Topex ellipsoid to the WGS84 ellipsoid. $H_{a l t}, H_{\text {ran }}$ and $H_{h e i}$ were given by the downloaded GDRs with the file name of alt_20hz, ice_range_20hz_ku, geoid respectively.

The correction parameter $\Delta H_{c o r}$ generally includes the range and geophysical corrections over the inland water bodies. For range correction, there are dry tropospheric correction, wet tropospheric correction and ionospheric correction. The geophysical corrections include earth tide and the pole tide corrections. The corrections are provided using mathematical formulas (Eq. 7):

$$
\Delta H_{c o}=I_{\text {iano }}+D_{d y y}+W_{\text {wet }}+P_{p t}+S_{e t}
$$

where $I_{\text {iono }}, D_{d r y}$ and $W_{\text {wet }}$ are the ionospheric correction, the dry tropospheric correction and the wet troposphere correction respectively and $P_{p t}$ and $S_{e t}$ are the pole tide and earth tide correction respectively. All the parameters were offered by the GDRs files.

Differences between heights at individual spots and the mean height were computed based the above preliminary results. The heights with continuous sequence number and differences less than $0.3 \mathrm{~m}$ were retained as the most valid data. And a new mean height was computed from the outlier-free heights, which represent the height of the pass. All the data were processed in BRAT (Basic Radar Altimetry Toolbox) software (https://www.aviso.altimetry.fr/en/data/tools.html), which was provided by the official website of AVISO.

\section{Mann-Kendall trend analysis}

The Mann-Kendall rank correlation test is a nonparametric statistical test method, which was developed to test the non-linear trend and turning point. It has the advantage of not requiring a sample to obey a certain distribution, nor interfering with a few outliers, which is more suitable for typed variables and ordinal variables. When the test statistic $|Z|>Z 1-\alpha / 2$, it represents that the time series data has a significant ascending or descending trend at the confidence level $\alpha$, and vice versa, the trend change is not significant. When the normalized statistic $\mathrm{Z}$ is positive, it indicates that the variables in the time series show an upward trend, with the negative values indicating a downward trend. When the absolute value of $\mathrm{Z}$ is equal or greater than $1.28,1.64$ or 2.32, demonstrating the significance tests were passed at the confidence coefficient of $90 \%$, $95 \%$, and $99 \%$ respectively. 


\section{Results}

\section{Comparison of the inundation area}

The inundation area of the Tonle Sap Lake in 2008-2018 was extracted by singleband threshold method, composite index and MNDWI respectively. Generally, the results of the three methods have presented similar variation trend and strong correlations (Table 1).

Table 1. The correlation of three methods and measured water level

\begin{tabular}{c|c|c|c|c}
\hline Methods & $\begin{array}{c}\text { Single-band } \\
\text { threshold method }\end{array}$ & $\begin{array}{c}\text { Composite } \\
\text { index }\end{array}$ & MNDWI & $\begin{array}{c}\text { Measured water } \\
\text { level }\end{array}$ \\
\hline Single-band threshold method & 1 & 0.979 & 0.940 & 0.900 \\
Composite index & 0.979 & 1 & 0.964 & 0.929 \\
MNDWI & 0.940 & 0.964 & 1 & 0.900 \\
\hline
\end{tabular}

The inundation area extracted by single-band threshold method was close to the composite index, while the result of MNDWI was obviously lower than the two methods, especially during the rainy season (Fig. 3). For example, the inundation area in September 2009 extracted by single-band threshold method, composite index and MNDWI was $17306.77 \mathrm{~km}^{2}, 18497.44 \mathrm{~km}^{2}$ and $10131.21 \mathrm{~km}^{2}$ respectively. However, the results of the three methods were close to each other in the dry season. The area of Tonle Sap Lake in rainy season is approximate six times larger than the dry season. In recent decade, the maximum inundation area of Tonle Sap Lake extended 5.9, 5.5 and 3.6 times extracted by the single-band threshold method, composite index and MNDWI respectively.

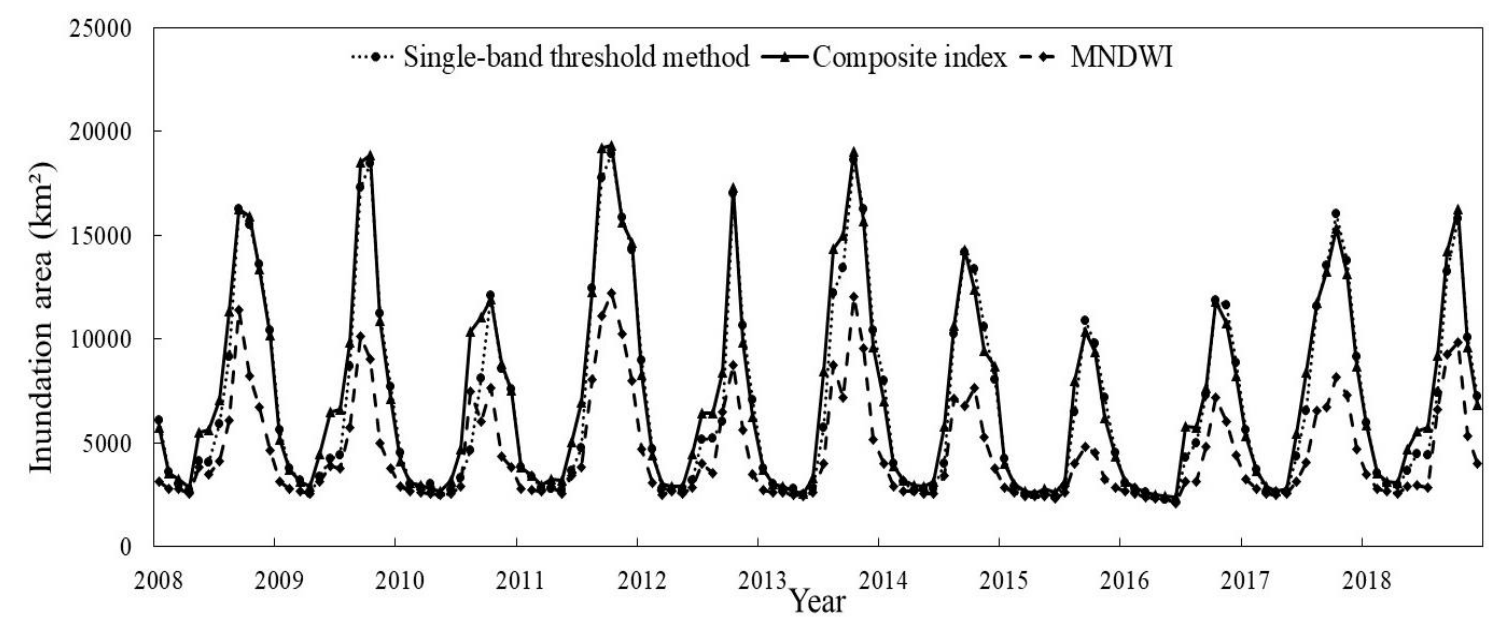

Figure 3. Inundation area of Tonle Sap Lake from January 2008 to December 2018 with three methods

The advantages and disadvantages of the three methods were quite different as can be observed from the spatial distribution of the extracted inundation area (Fig. 4). The composite index was able to extract water bodies with smaller area, such as the channel of Tonle River in the dry season (Fig. 4a), while the other two methods were incapable 
of identify the smaller water area. This could because the composite method combined the EVI and the LSWI, and the difference between them enhances the contrast between water and background objects, which made it better to distinguish the water body and extract with mixed pixels (Frappart et al., 2018; Normandin et al., 2018). The MNDWI enhanced the contrast between the water body and the building, which greatly reduced the confounding effect of ground buildings (Du et al., 2016). It was more appropriate to identify water body with clear boundaries. Although single-band threshold method was easy to implement and was insusceptible to the quality of the images, it had problem to distinguish the water body within mixed pixels.
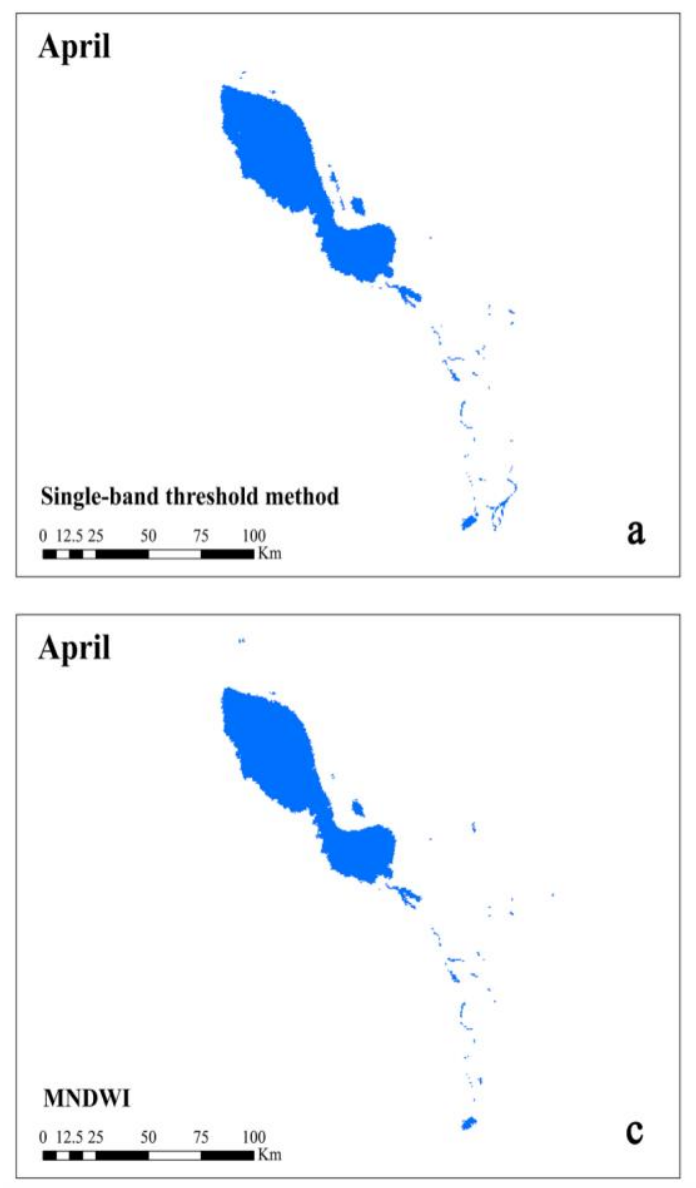

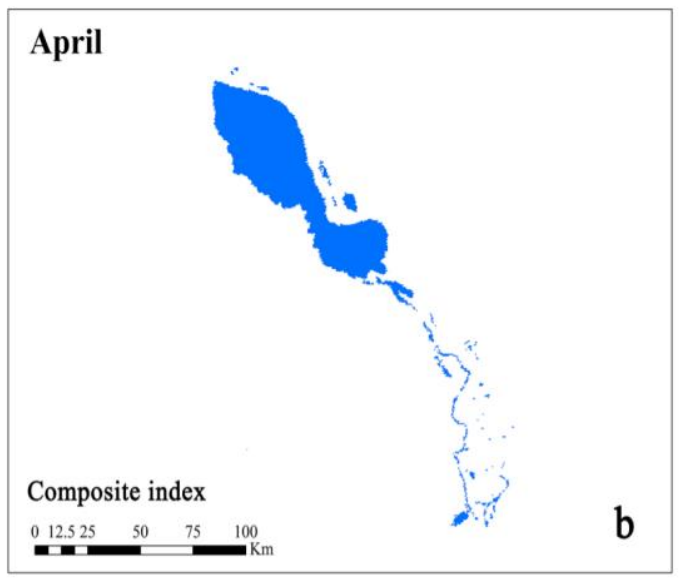

Legend $\square$ The water area of Tonle Sap Lake

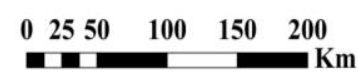

Figure 4. Comparison of spatial distribution of water body in the Tonle Sap Lake

Therefore, the composite index was the optimal method to identify the inundation area of the Tonle Sap Lake, followed by the single-band threshold method and MNDWI, in the case of the same spatial resolution.

\section{Accuracy of altimetry water level}

The data of the Prek Kdam hydrological station was downloaded from the official website of the MRC and was used as the measured data of the water level of the Tonle Sap Lake. The site is located on the Tonle Sap River, about $86 \mathrm{~km}$ away from the location where Jason-2 and Jason-3 radar altimeter monitored. Therefore, there were differences between measured data and satellite results due to gaps of the height datum, 
terrain and observation time. And as only part of the data was published to the public, about 100 measured water levels from 2008 to 2018 were obtained to verify the altimeter data. Compared to the in situ measured water levels, the water levels observed by Jason-2 and Jason-3 radar altimetry were a little bit higher (Fig. 5). Although there were differences between the two datasets, the variation trend was similar and extreme values were generally appeared in the same period of time.

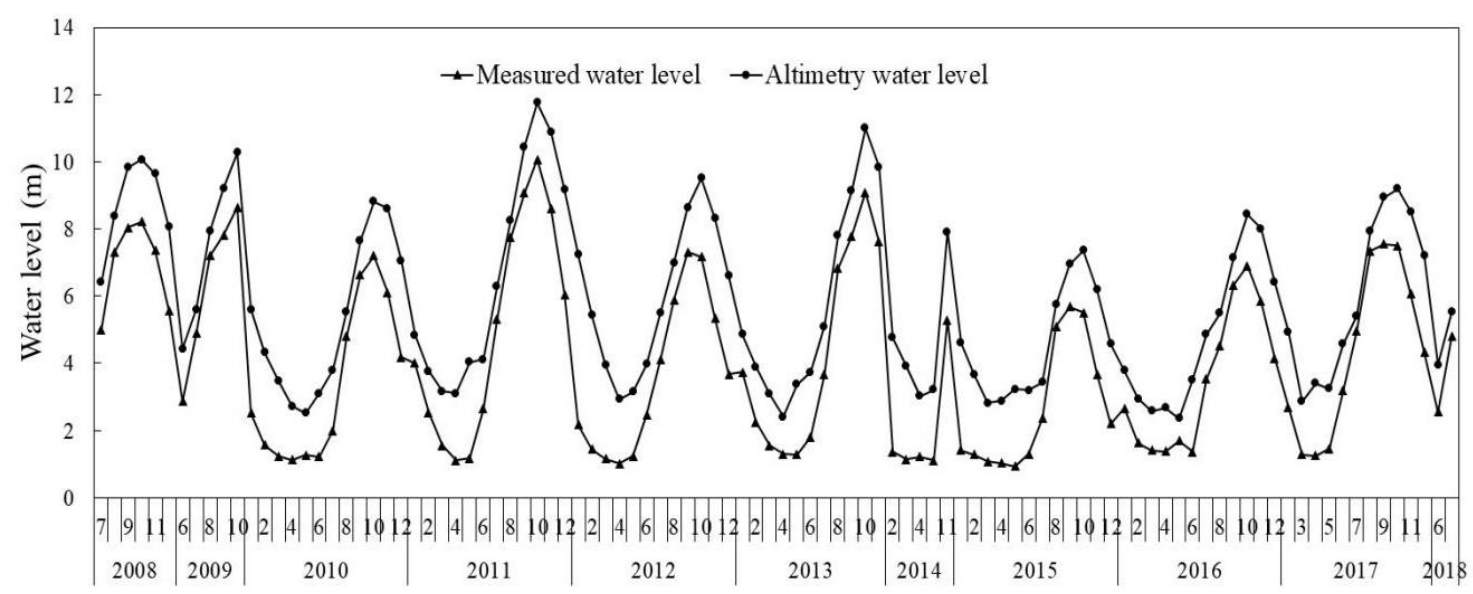

Figure 5. Comparison of altimetry water level and measured water level in 2008-2018

Linear correlation analysis indicated a significant positive correlation between measured water levels and the water levels observed by Jason-2 and Jason-3 radar altimetry with $\mathrm{R}^{2}=0.9232$ and confidence coefficient of $98 \%$ (Fig. 6). It was demonstrated that the Jason-2 and Jason-3 radar altimetry data were reliable to detect the inland water level like Tonle Sap Lake with high accuracy.

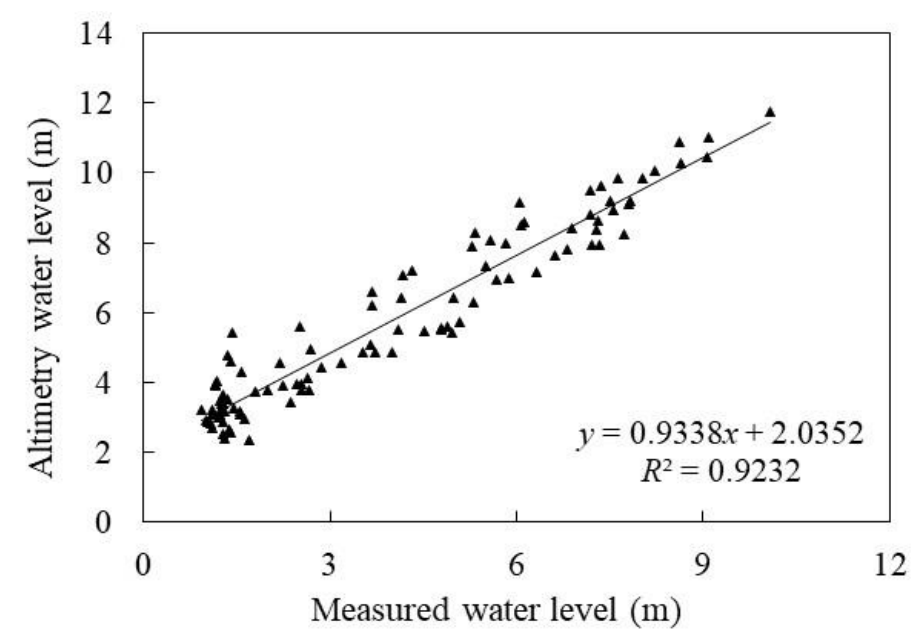

Figure 6. Scatter plot of the altimetry water level and the measured water level

\section{Changing trend of inundation area and water level}

Linear tendency estimation, moving average and Mann-Kendall trend analysis were applied to analyze the changing trend of inundation area and water level. The slope rates 
of linear equation for inundation area and water level were -151.96 and -0.11 , with both of them presented decline trend. As well as the 3-year sliding average, the inundation area and water level appeared decreasing tendency with fairy fluctuation from 2008 to 2018 (Fig. 7).
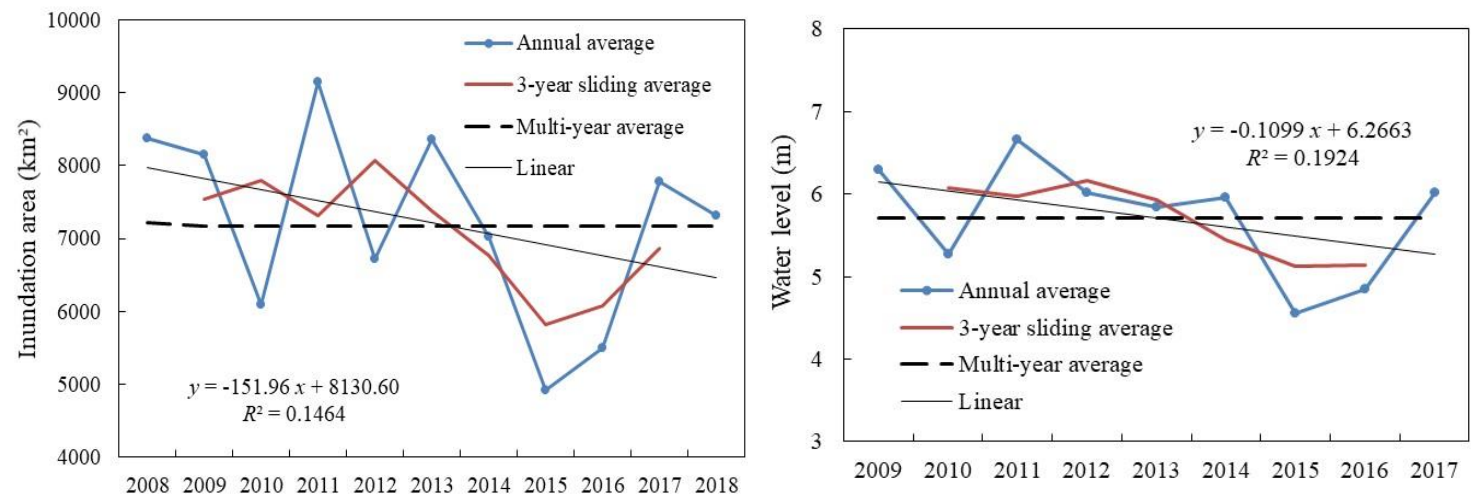

Figure 7. Linear tendency and moving average of inundation area and water level in the study area

The $\mathrm{Z}$ values of Mann-Kendall were -1.09 and -0.8 for inundation area and water level respectively, and both the absolute values were less than 1.96, which indicated that both the inundation area and water level shown the decline trend. In consequence, the inundation area of the Tonle Sap Lake shrinking gradually and the water level declined in the past decade.

\section{Discussion}

\section{Variation of inundation area}

As can be observed from the spatial distribution of the inundation area of the Tonle Sap Lake, the large inundation area was generally distributed along with the north and south tributaries, where the Ramsar wetland and Tonle Sap Biosphere Reserve located, and then expanded to northwest part (Fig. 8). This was consistent with the results of previous studies carried out by Kummu et al., which documented that the floods in the Tonle Sap Lake mostly occurred in the western part of the lake (Kummu et al., 2014).

The variation trend of the inundation area was similar on annual scale, but varied within the year with seasonal cycle (Fig. 9). The minimum inundation area always appeared in April or May, while the maximum area generally turned up during September and November. The characteristics were accordance with finding from previous studies (Arias et al., 2012, 2014). In the rainy season, followed by the increasing precipitation, the water level of the mainstream of Mekong River increased which forcing the water flows to Tonle Sap Lake through Tonle Sap River and resulting the inundation area expanded promptly. When the dry seasons came and the precipitation decreased, the water in Tonle Sap Lake flowed back to replenish the Mekong River and nourished the Mekong Delta. This was obvious in the northwestern part of the lake, where the inundation area decreased dramatically. 

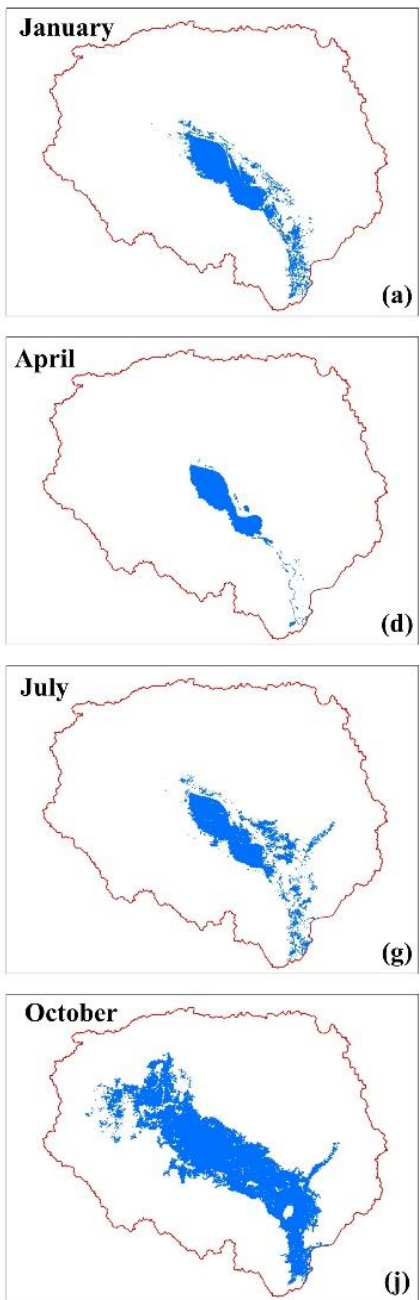

(j)
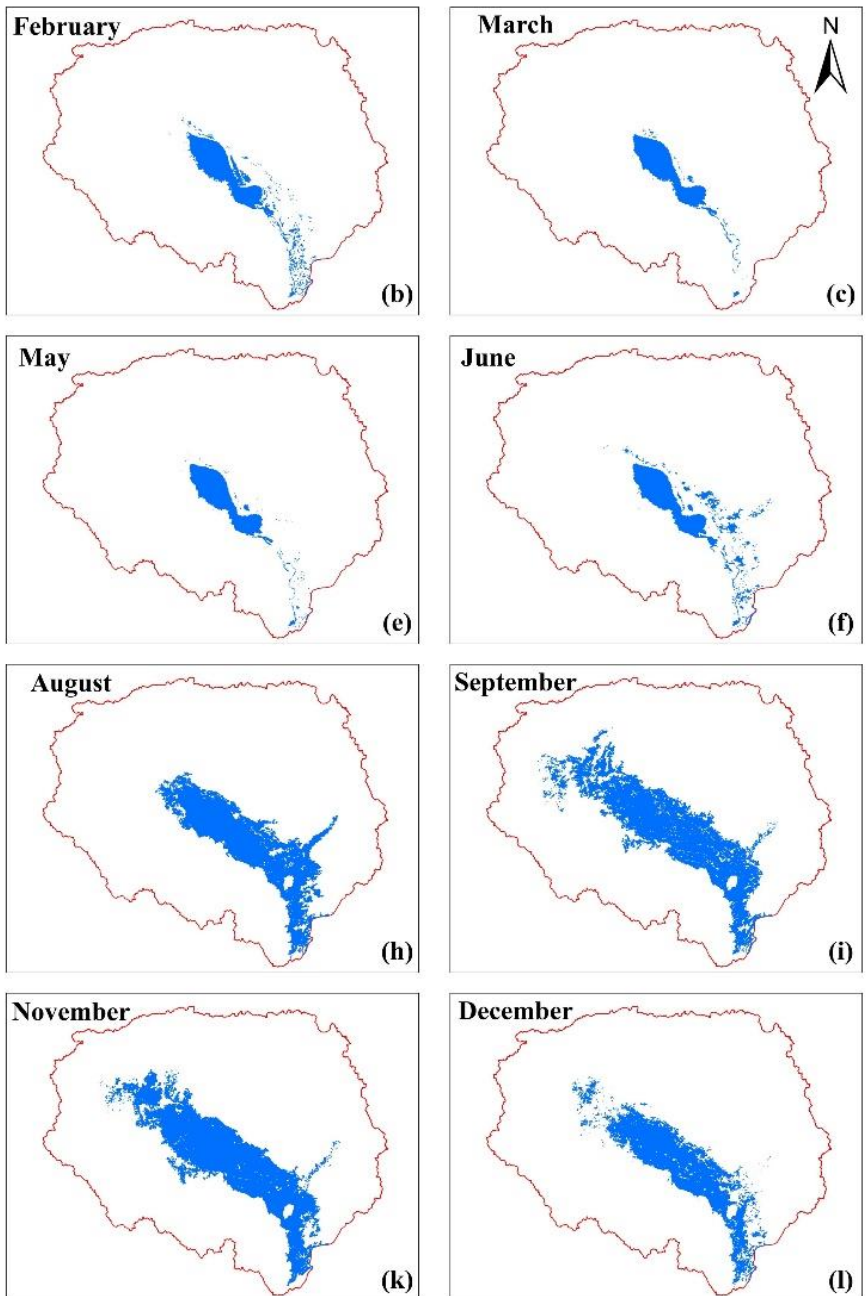

(k)

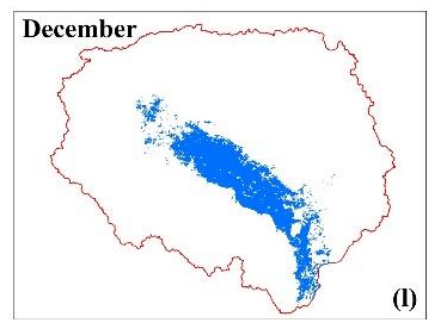

(I)

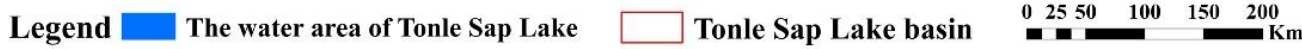

Figure 8. Spatial distribution of inundation area in the Tonle Sap Lake in 2017

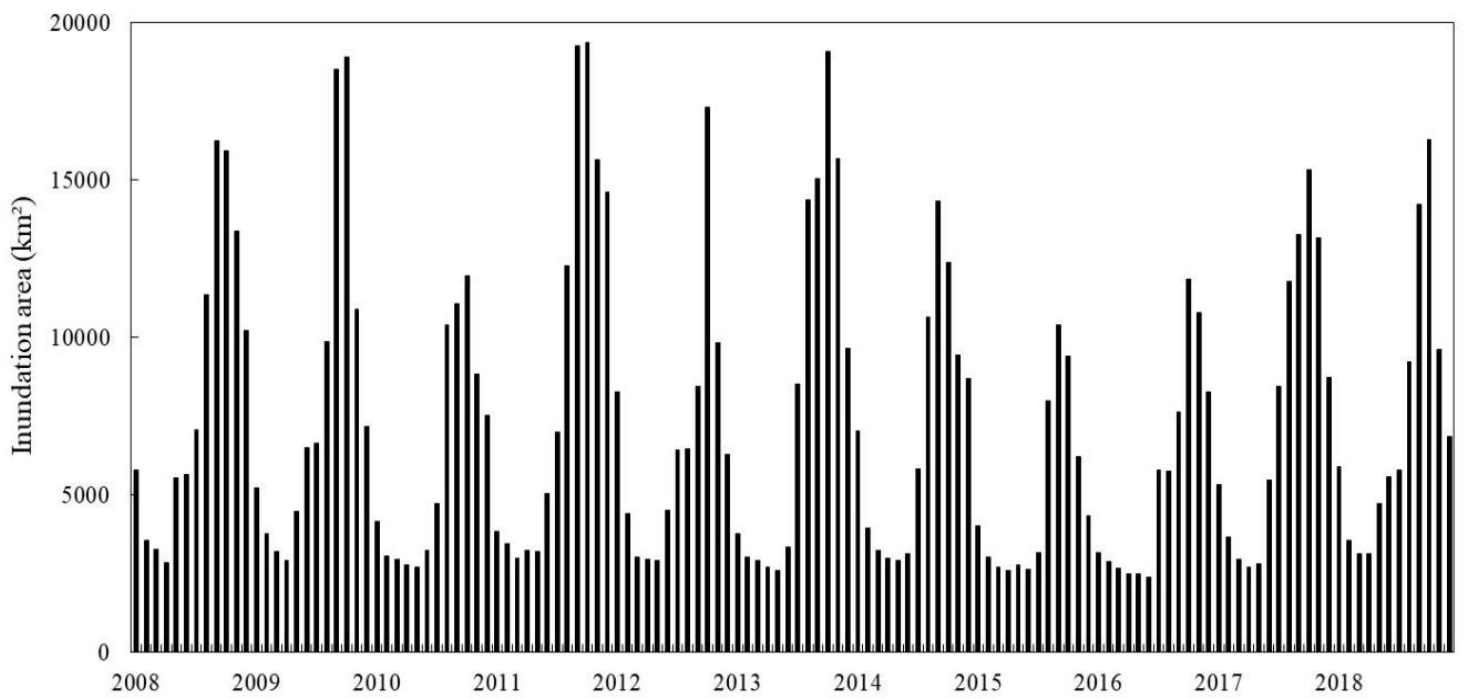

Figure 9. Monthly average inundation area of the study area from 2008 to 2018 
The minimum inundation area reached $2265.80 \mathrm{~km}^{2}$ and $2736.79 \mathrm{~km}^{2}$ in 2016 and 2009 , which were both dry years, and presented relatively less inter-annual variations in dry seasons. Due to the impact of the El Niño happened at the end of 2014, the entire Mekong River Basin was suffered with severe drought, reduced precipitation and runoff (Frappart et al., 2018), which led to little water could be injected into the Tonle Sap Lake during the rainy season. However, the inundation area has shown significant interannual variations in rainy seasons, with the maximum inundation area varied from $10623.66 \mathrm{~km}^{2}$ in September 2015 to $19144.58 \mathrm{~km}^{2}$ in October 2011, when the catastrophic flood occurred in 2011 in the Tonle Sap Lake.

\section{Variation of water level}

The monthly water level of Tonle Sap Lake was monitored by the Jason-2 and Jason3 radar altimetry from 2008 to 2018 (Fig. 10). In general, the lowest water level appeared in April or May and the highest water level appeared during September to November. April and May are the late stage of the dry season per year, the lake continued to evaporate without plenty precipitation to supply, the water level could reach the minimum of $2.36 \mathrm{~m}$. Whereas during September to October, the late stage of rainy season, the water supply continued and led to the possibility to reach the highest water level during this period. The water level varied significant over the period of one year and steady trend was observed in the inter-annual scale.

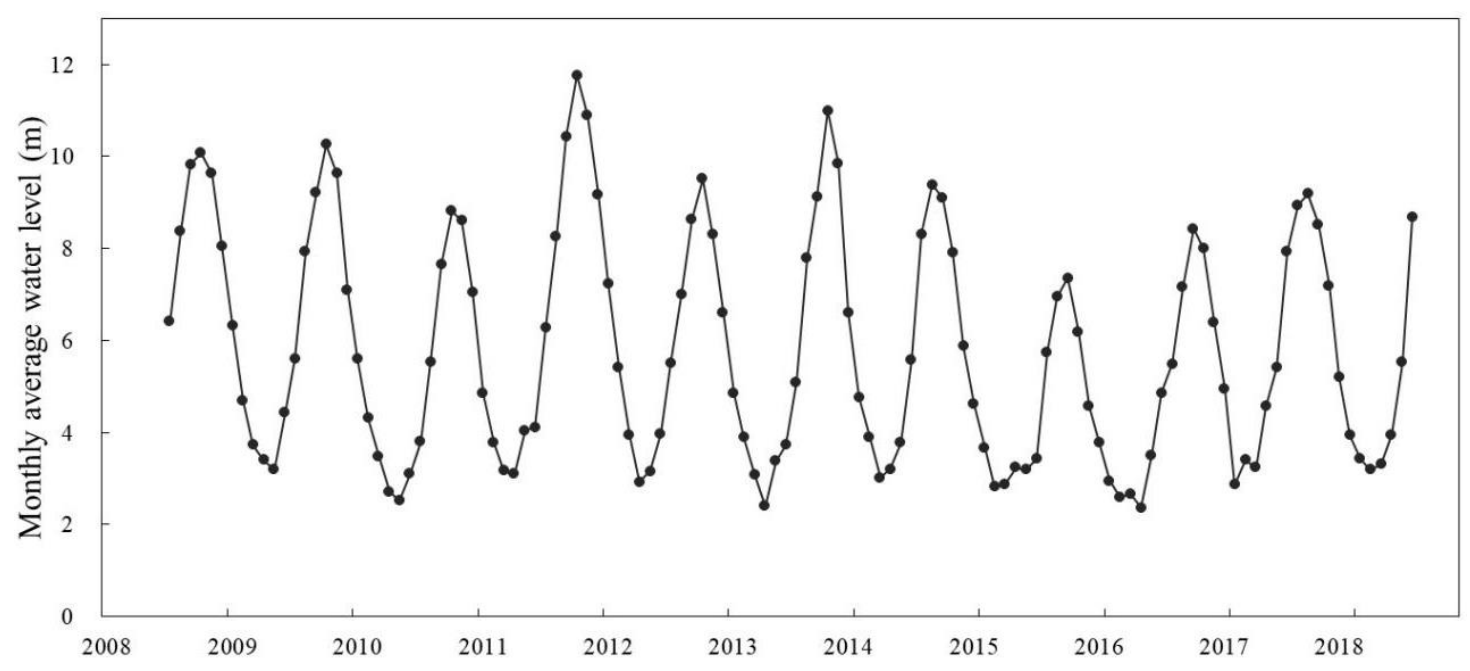

Figure 10. Estimated monthly average water level of the Tonle Sap Lake from 2008 to 2018

Take the water level of flood year 2011 and drought year 2015 as the example, the water level escalated from May to October and presented decline trend from November to May of next year (Fig. 11). The variation tendency of water level in flood year was fairly consistent with the drought year. During the rainy season from June to October, the differences of water level between flood year and drought year increased progressively and reached the highest value $4.42 \mathrm{~m}$ in October. The differences of water level showed relatively little change from January to April with water levels close to each other.

As the catastrophic flood occurred in 2011, the water level reached the maximum of $11.76 \mathrm{~m}$ in October. And due to the impact of El Niño from the end of 2014, the ambient countries all suffered from severe drought, especially downstream of the Mekong Delta. 
The water level of Tonle Sap Lake reached the minimum of $7.35 \mathrm{~m}$ in October 2015. The altimetry water level was able to derive reliable water levels which was quite consistence with the actual situation. The result was expected to provide a reference for the practice of deriving water level of medium water bodies by altimetry satellites.

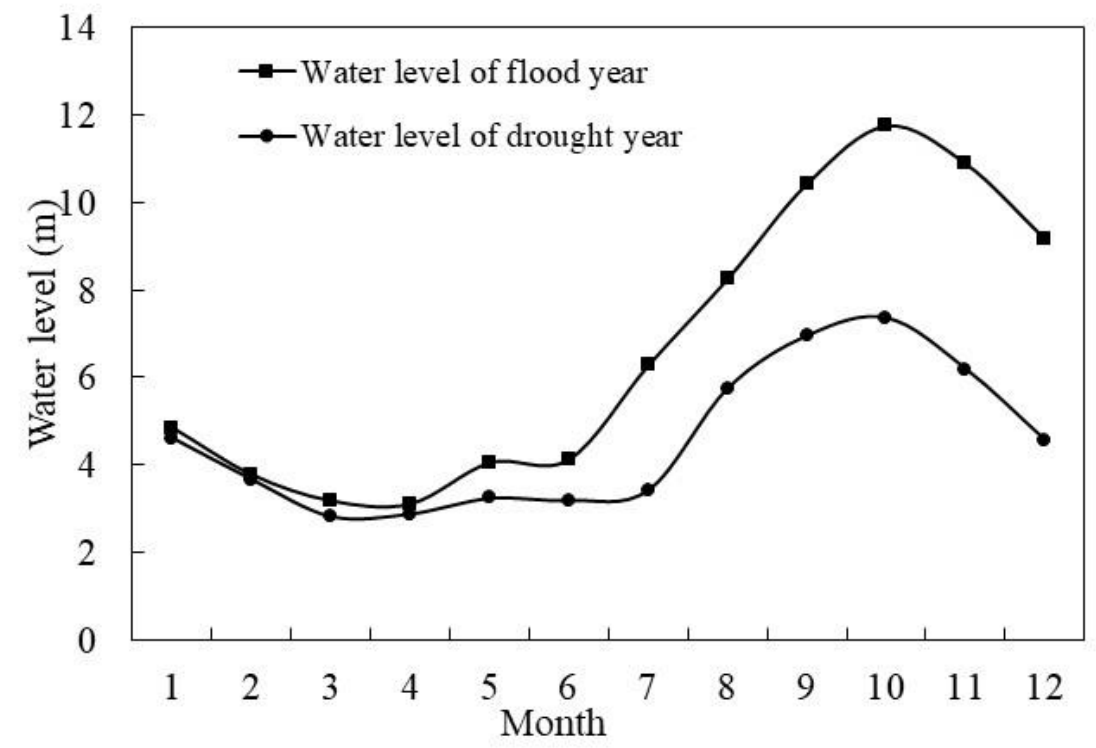

Figure 11. Comparison of water level in drought year (2015) and flood year (2011)

\section{Response to precipitation}

Combined with the monthly precipitation data from TRMM 3B42V7, the fluctuation trend of inundation area (Fig. 12) and water level (Fig. 13) were basically consistent with the precipitation. However, the time lags of the extremes (both the minimum and the maximum) between inundation area/water level and precipitation were approximate one month, which was a distinct lagging relationship. The findings of Kummu et al. demonstrated that more than half of the annual flow into the Tonle Sap came from Mekong River, $34 \%$ from the tributaries and $12.5 \%$ from precipitation (Kummu et al., 2014). And the runoff of Mekong River is mainly from precipitation. Therefore, the variation of inundation area and water level in the Tonle Sap Lake were closely related to the change of precipitation, which were driven by the monsoon flood in the Mekong River Basin.

In the past decade, both the precipitation of the Tonle Sap Lake Basin (Fig. 14a) and the Mekong River Basin (Fig. 14b) presented declined trend which were not significant. If the precipitation decreases, the runoff of the Mekong River will go down correspondingly. As a result, the discharge flows into Tonle Sap Lake in the rainy seasons will decrease and the water level will decline as well. These phenomena happened in 2015, after the El Niño phenomenon occurred in the Mekong River Basin with the sudden drop of precipitation and climate warming. The precipitation of Mekong River Basin in 2015 was only $1567.08 \mathrm{~mm}$, which was 13.29\% lower compared to the average annual precipitation. In consequence, the inundation area decreased $29.75 \%$ and water level declined $20.33 \%$ in comparison with the average annual values. 


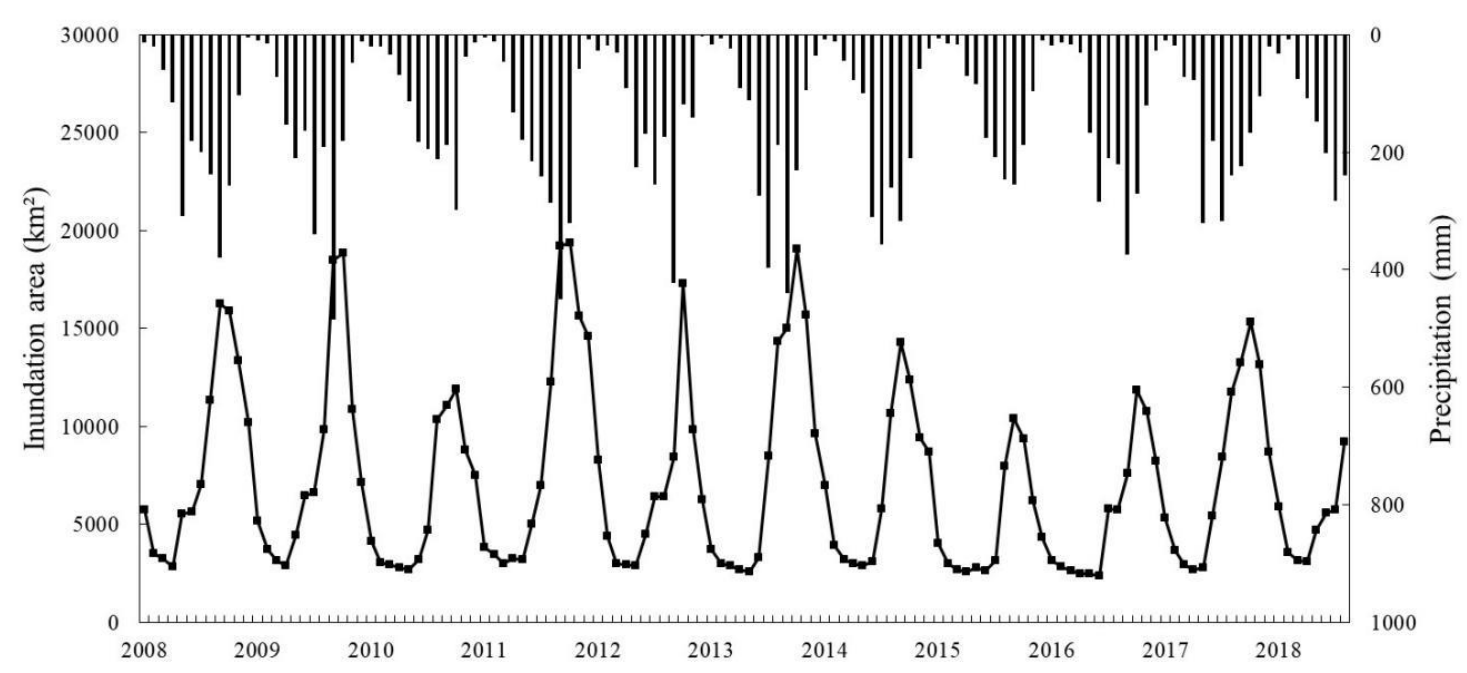

Figure 12. Comparison of inundation area and precipitation

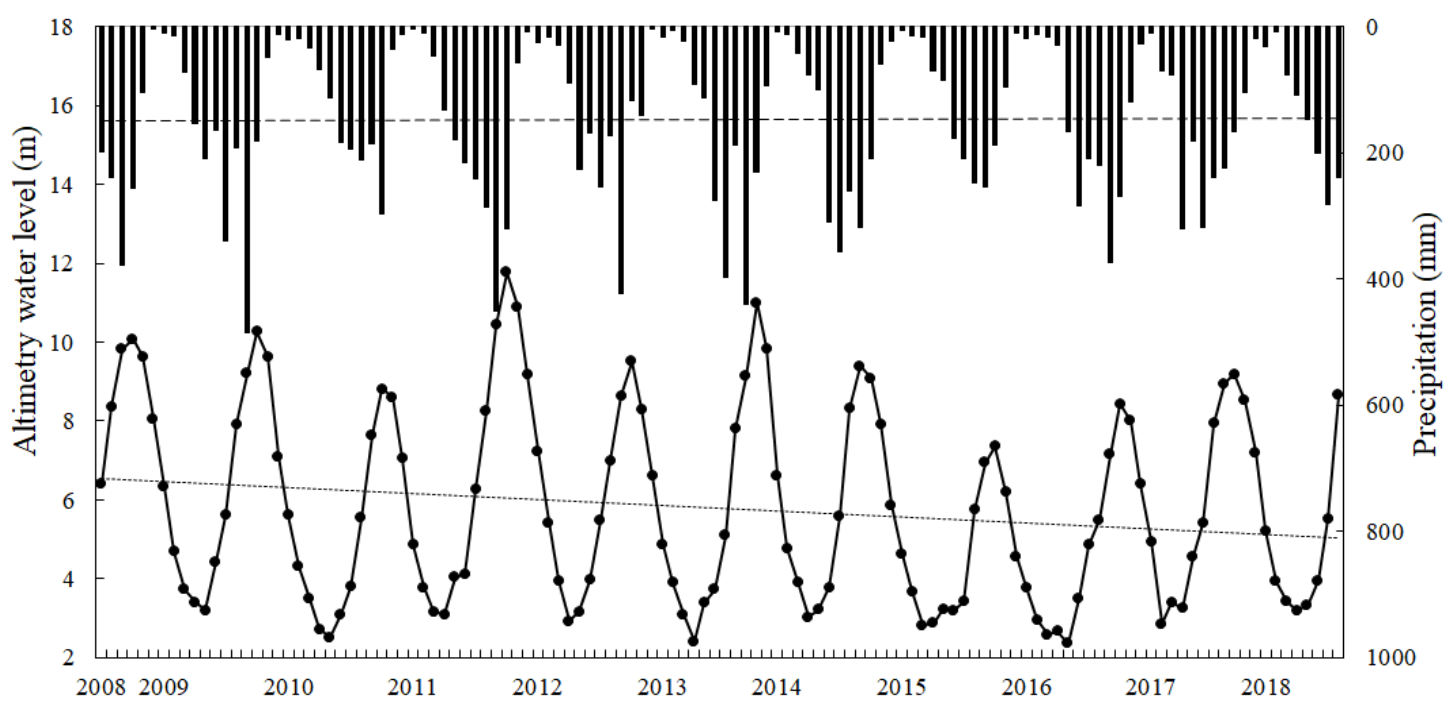

Figure 13. Comparison of water level and precipitation
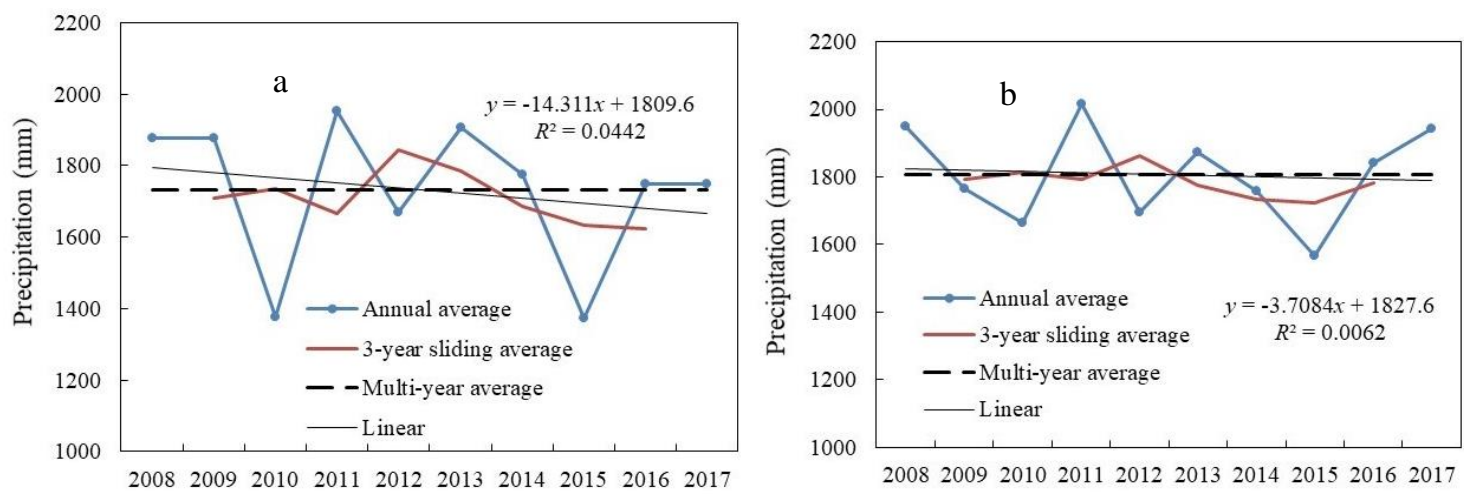

Figure 14. Linear tendency and moving average of precipitation of Tonle Sap Lake basin and Mekong River basin 
Moreover, plenty of sediments brought by the floods and the deforestation around the lake have caused massive deposit in the inundation area, which could give rise to the shrinking of the water body. The area already decreased at the speed of $30 \mathrm{~km}^{2}$ per year. At the same time, construction of the dams on the tributary of Tonle Sap River reduced the surface water that flowed into Tonle Sap Lake (Arias et al., 2019).

\section{Response to the upstream hydrology regime}

Conflicts often arise over the Lancang-Mekong River, since it spread across the six riparian countries with more than 70 dams. Different stakeholders compete for the scarce water resources and limited reservoir storage capacity. As the largest boundary lake that regulates and stores the flood from this controversial transnational river, the water regime of the Tonle Sap Lake also attracted extensive attention worldwide.

Some international media reported that the decline of downstream water level was attributed to the exploration of the upstream countries, especially the dam construction over the Lancang River in China. The disputes of whether the upstream exploitation such as dam construction and hydropower station have definitely negative effects on downstream water resource utilization have been lasted for several decades (Lu et al., 2014).

However, our result demonstrated that the average water level derived from the radar altimeter did not follow the change of the average runoff from Jinghong hydrological station $\left(100^{\circ} 47^{\prime} \mathrm{E}, 22^{\circ} 02^{\prime} \mathrm{N}\right)$ distinctly, which is the last control station that located in the upstream of the Lancang-Mekong river in China, both in flood period and non-flood periods (Fig. 15). Although, the Chinese government was requested to increase the discharge to alleviate the drought in the downstream since the El Niño event in 2014, the water level also declined slightly. This was also proved by other research, which found that the shrinking water area of Tonle Sap Lake was not attributed to the development of the Lancang cascade hydropower stations (Ji et al., 2018).

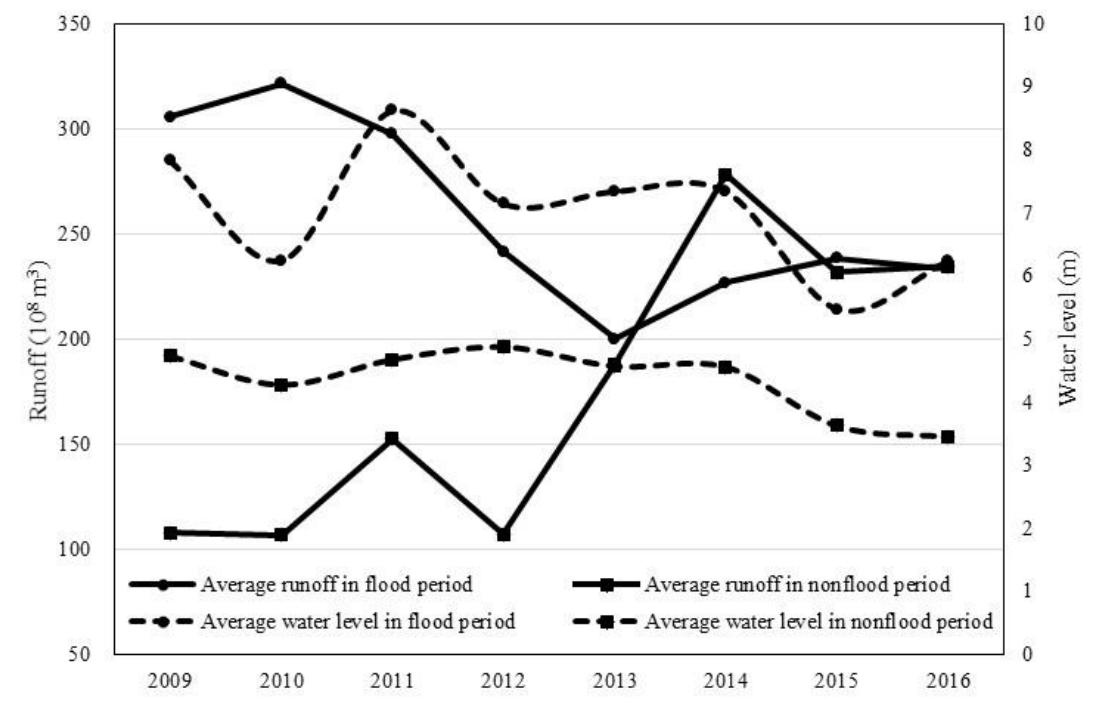

Figure 15. Distribution of average runoff and water level in flood and non-flood periods

The correlation coefficients between average water level and runoff in flood period and non-flood periods were 0.0542 and 0.2873 with $p<0.01$ (Fig. 16), which presented the poor correlation between the downstream water level and the upstream runoff. 


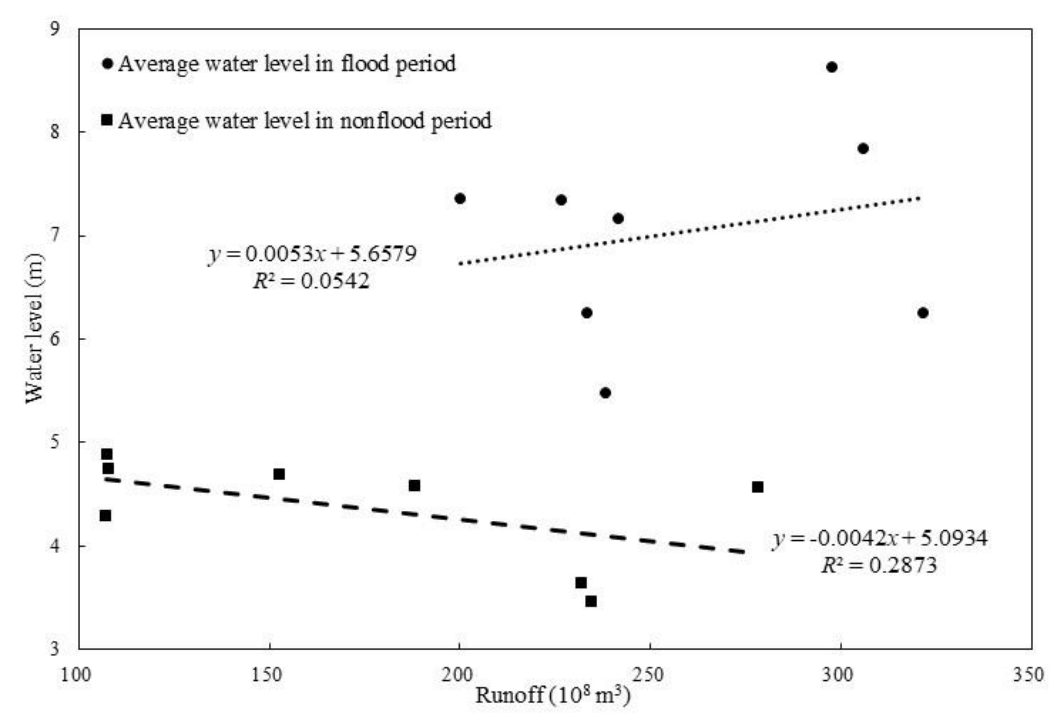

Figure 16. Correlation between average runoff and water level in flood and non-flood periods

Coincidentally, results from other researches also indicated no major difference in flows between the pre- and post-development of hydropower projects. And the inclusion of a few major dams resulted in decreased river streamflow of $6 \%$ to $15 \%$ possibly due to irrigation diversions and climate change (Fan et al., 2015; Lu et al., 2014; Sridhar et al., 2019).

\section{Conclusions}

Our study provided a comprehensive assessment of the variations of the inundation area as well as to explore water levels in the Tonle Sap Lake over the past decade, using various data sets delivered by remote sensing satellites. It was demonstrated that the Jason-2 and Jason-3 radar altimetry data were reliable to detect the inland water level like Tonle Sap Lake with high accuracy $\left(\mathrm{R}^{2}=0.9232\right.$ and confidence coefficient of 98\%). And the composite index was the optimal method to identify inundation area of the Tonle Sap Lake, due to the difference between EVI and LSWI, which enhanced the contrast between water and background objects and made it better to distinguish the water body and extract with mixed pixels compared to the other two methods.

The fluctuation trend of inundation area and water level were basically consistent with the precipitation, presented a distinct lagging relationship. And the time lags of the extremes (both the minimum and the maximum) between inundation area/water level and precipitation were approximate one month. The variation of inundation area and water level in the Tonle Sap Lake were closely related to the change of precipitation. Moreover, the runoff from upstream hydropower station presented poor correlation with the downstream water level both in flood period and non-flood periods, which indicated that the upstream explorations over Lancang-Mekong River had little effects on the downstream water volume.

In the future, we would like to explore some other altimetry mission in order to obtain finer temporal and spatial resolution water levels, which were expected to provide more details. We will also apply the proposed technology to some other poorly gauged river basins to expand our knowledge of radar altimetry. 
Acknowledgments. This research was funded by National Natural Science Foundation of China (NO. 41661085, 41763004, 41461021), Guangxi Scientific Project (NO. AD19110140), Guangxi Scholarship Fund of Guangxi Education Department, "Specially Employed Expert" project of Guangxi Zhuang Autonomous Region.

\section{REFERENCES}

[1] Amani, M., Salehi, B., Mahdavi, S., Granger, J. E., Brisco, B., Hanson, A. (2017): Wetland classification using multi-source and multi-temporal optical remote sensing data in Newfoundland and Labrador, Canada. - Canadian Journal of Remote Sensing 43(4): 360-373.

[2] Arias, M. E., Cochrane, T. A., Piman, T., Kummu, M., Caruso, B. S., Killeen, T. J. (2012): Quantifying changes in flooding and habitats in the Tonle Sap Lake (Cambodia) caused by water infrastructure development and climate change in the Mekong Basin. Journal of Environmental Management 112: 53-66.

[3] Arias, M. E., Cochrane, T. A., Kummu, M., Lauri, H., Holtgrieve, G. W., Koponen, J., Piman, T. (2014): Impacts of hydropower and climate change on drivers of ecological productivity of Southeast Asia's most important wetland. - Ecological Modelling 272: 252-263.

[4] Arias, M. E., Holtgrieve, G. W., Ngor, P. B., Dang, T. D., Piman, T. (2019): Maintaining perspective of ongoing environmental change in the Mekong floodplains. - Current Opinion in Environmental Sustainability 37: 1-7.

[5] Biancamaria, S., Schaedele, T., Blumstein, D., Frappart, F., Boy, F., Desjonqueres, J. D., Pottier, C., Blarel, F., Nino, F. (2018): Validation of Jason-3 tracking modes over French rivers. - Remote Sensing of Environment 209: 77-89.

[6] Boergens, E., Dettmering, D., Seitz, F. (2019): Observing water level extremes in the Mekong River Basin: The benefit of long-repeat orbit missions in a multi-mission satellite altimetry approach. - Journal of Hydrology 570: 463-472.

[7] Breda, J., Paiva, R. C. D., Bravo, J. M., Passaia, O. A., Moreira, D. M. (2019): Assimilation of satellite altimetry data for effective river bathymetry. - Water Resources Research 55(9): 7441-7463.

[8] Chen, Y., Huang, C., Ticehurst, C., Merrin, L., Thew, P. (2013): An evaluation of MODIS daily and 8-day composite products for floodplain and wetland inundation mapping. - Wetlands 33(5): 823-835.

[9] Ding, X. W., Li, X. F. (2011): Monitoring of the water-area variations of Lake Dongting in China with ENVISAT ASAR images. - International Journal of Applied Earth Observation and Geoinformation 13(6): 894-901.

[10] Du, Y., Zhang, Y. H., Ling, F., Wang, Q. M., Li, W. B., Li, X. D. (2016): Water bodies' mapping from Sentinel-2 imagery with modified normalized difference water index at 10$m$ spatial resolution produced by sharpening the SWIR band. - Remote Sensing 8(4): 119.

[11] Dubey, A. K., Gupta, P. K., Dutta, S., Singh, R. P. (2015): An improved methodology to estimate river stage and discharge using Jason-2 satellite data. - Journal of Hydrology 529: 1776-1787.

[12] Fan, H., He, D. M., Wang, H. L. (2015): Environmental consequences of damming the mainstream Lancang-Mekong River: a review. - Earth-Science Reviews 146: 77-91.

[13] Fan, X. W., Liu, Y. B., Wu, G. P., Zhao, X. S. (2020): Compositing the minimum NDVI for daily water surface mapping. - Remote Sensing 12(4): 700

[14] Fayne, J. V., Bolten, J. D., Doyle, C. S., Fuhrmann, S., Rice, M. T., Houser, P. R., Lakshmi, V. (2017): Flood mapping in the lower Mekong River Basin using daily MODIS observations. - International Journal of Remote Sensing 38(6): 1737-1757. 
[15] Feng, L., Hu, C. M., Chen, X. L., Cai, X. B., Tian, L. Q., Gan, W. X. (2012): Assessment of inundation changes of Poyang Lake using MODIS observations between 2000 and 2010. - Remote Sensing of Environment 121: 80-92.

[16] Frappart, F., Biancamaria, S., Normandin, C., Blarel, F., Bourrel, L., Aumont, M., Azemar, P., Vu, P. L., Le Toan, T., Lubac, B., Darrozes, J. (2018): Influence of recent climatic events on the surface water storage of the Tonle Sap Lake. - Science of the Total Environment 636: 1520-1533.

[17] Gleason, C. J., Hamdan, A. N. (2017): Crossing the (watershed) divide: satellite data and the changing politics of international river basins. - Geographical Journal 183(1): 2-15.

[18] Hecht, J. S., Lacombe, G., Arias, M. E., Dang, T. D., Piman, T. (2019): Hydropower dams of the Mekong River basin: a review of their hydrological impacts. - Journal of Hydrology 568: 285-300.

[19] Huang, Q., Long, D., Du, M. D., Zeng, C., Li, X. D., Hou, A. Z., Hong, Y. (2018): An improved approach to monitoring Brahmaputra River water levels using retracked altimetry data. - Remote Sensing of Environment 211: 112-128.

[20] Jahanbakhsh, G., M., Khorasani, N., Morshedi, J., Danehkar, A., Naderi, M. (2017): An investigation on spatial changes of Parishan international wetland using remote sensing methods. - Applied Ecology and Environmental Research 15(3), 549-562.

[21] Ji, X., Li, Y. G., Luo, X., He, D. M. (2018): Changes in the lake area of Tonle Sap: possible linkage to runoff alterations in the Lancang River? - Remote Sensing 10: 866.

[22] Kummu, M., Tes, S., Yin, S., Adamson, P., Jozsa, J., Koponen, J., Richey, J., Sarkkula, J. (2014): Water balance analysis for the Tonle Sap Lake-floodplain system. - Hydrological Processes 28(4): 1722-1733.

[23] Kuo, C. Y., Cheng, Y. J., Lan, W. H., Kao, H. C. (2015): Monitoring vertical land motions in southwestern Taiwan with retracked Topex/Poseidon and Jason-2 satellite altimetry. - Remote Sensing 7(4): 3808-3825.

[24] Kwak, Y. J. (2017): Nationwide flood monitoring for disaster risk reduction using multiple satellite data. - ISPRS International Journal of Geo-Information 6(7): 203.

[25] Larnberts, D., and Koponen, J. (2008): Flood pulse alterations and productivity of the Tonle Sap ecosystem: a model for impact assessment. - Ambio 37(3): 178-184.

[26] Li, W. B., Du, Z. Q., Ling, F., Zhou, D. B., Wang, H. L., Gui, Y. M., Sun, B. Y., Zhang, X. M. (2013): A comparison of land surface water mapping using the normalized difference water index from TM, ETM plus and ALI. - Remote Sensing 5(11): 55305549.

[27] Li, D. N., Zhao, J. S., Govindaraju, R. S. (2019a): Water benefits sharing under transboundary cooperation in the Lancang-Mekong River Basin. - Journal of Hydrology 577: 1-13.

[28] Li, X. D., Long, D., Huang, Q., Han, P. F., Zhao, F. Y., Wada, Y. (2019b): Hightemporal-resolution water level and storage change data sets for lakes on the Tibetan Plateau during 2000-2017 using multiple altimetric missions and Landsat-derived lake shoreline positions. - Earth System Science Data 11(4): 1603-1627.

[29] Lu, X. X., Li, S. Y., Kummu, M., Padawangi, R., Wang, J. J. (2014): Observed changes in the water flow at Chiang Saen in the lower Mekong: Impacts of Chinese dams? Quaternary International 336: 145-157.

[30] Maillard, P., Bercher, N., Calmant, S. (2015): New processing approaches on the retrieval of water levels in Envisat and SARAL radar altimetry over rivers: A case study of the Sao Francisco River, Brazil. - Remote Sensing of Environment 156: 226-241.

[31] Maiwald, F., Montes, O., Padmanabhan, S., Michaels, D., Kitiyakara, A., Jarnot, R., Brown, S. T., Dawson, D., Wu, A., Hatch, W., Stek, P., Gaier, T. (2016): Reliable and stable radiometers for Jason-3. - IEEE Journal of Selected Topics in Applied Earth Observations and Remote Sensing 9(6): 2754-2762. 
[32] Millard, K., Richardson, M. (2013): Wetland mapping with LiDAR derivatives, SAR polarimetric decompositions, and LiDAR-SAR fusion using a random forest classifier. Canadian Journal of Remote Sensing 39(4): 290-307.

[33] Normandin, C., Frappart, F., Lubac, B., Belanger, S., Marieu, V., Blarel, F., Robinet, A., Guiastrennec-Faugas, L. (2018): Quantification of surface water volume changes in the Mackenzie Delta using satellite multi-mission data. - Hydrology and Earth System Sciences 22(2): 1543-1561.

[34] Oeurng, C., Cochrane, T. A., Chung, S., Kondolf, M. G., Piman, T., Arias, M. E. (2019): Assessing climate change impacts on river flows in the Tonle Sap Lake Basin, Cambodia. - Water 11(3): 618.

[35] Pekel, J. F., Cottam, A., Gorelick, N., Belward, A. S. (2016): High-resolution mapping of global surface water and its long-term changes. - Nature 540(7633): 418-422.

[36] Schlaffer, S., Matgen, P., Hollaus, M., Wagner, W. (2015): Flood detection from multitemporal SAR data using harmonic analysis and change detection. - International Journal of Applied Earth Observation and Geoinformation 38: 15-24.

[37] Schneider, P., Hook, S. J. (2010): Space observations of inland water bodies show rapid surface warming since 1985. - Geophysical Research Letters 37(22): L22405.

[38] Sridhar, V., Kang, H., Ali, S. A. (2019): Human-induced alterations to land use and climate and their responses for hydrology and water management in the Mekong River Basin. - Water 11(6): 1307.

[39] Tangdamrongsub, N., Ditmar, P. G., Steele-Dunne, S. C., Gunter, B. C., Sutanudjaja, E. H. (2016): Assessing total water storage and identifying flood events over Tonle Sap basin in Cambodia using GRACE and MODIS satellite observations combined with hydrological models. - Remote Sensing of Environment 181: 162-173.

[40] Wang, H. H., Chu, Y. H., Huang, Z. K., Hwang, C., Chao, N. F. (2019): Robust, longterm lake level change from multiple satellite altimeters in Tibet: observing the rapid rise of Ngangzi Co over a New Wetland. - Remote Sensing 11(5): 558.

[41] Zhang, X. J., Qu, Y. P., Ma, M. M., Liu, H., Su, Z. C., Lv, J., Peng, J., Leng, G. Y., He, X. G., Di, C. L. (2020): Satellite-based operational real-time drought monitoring in the transboundary Lancang-Mekong River Basin. - Remote Sensing 12(3): 376. 